\title{
THE EKSTATIC ANIMAL IN JAN PATOČKA'S PHENOMENOLOGY
}

\author{
RICCARDO PAPARUSSO
}

\begin{abstract}
In this contribution, I discuss the thesis of the ontological difference between human and animal (zviŕe) existence within the framework of Jan Patočka's phenomenology. According to Patočkian phenomenological thought, this difference is possible only if the process of differentiation itself ripens - during its development - the seeds of openness to the truth that have been sowed in the land of the animal. Therefore, the dynamic of human elevation from the animal dimension constantly drags existence towards the field of the living. As a consequence, an inevitable yet unconcluded movement of mutual confluence between the animal mode of being and that of the human is brought to light and renovated. In his fleeting analysis of the animal, Patočka often seems to establish a net ontological difference between the 'animal being' and the 'human being. Nevertheless, the following article seeks to demonstrate that his phenomenological work is threaded with insights that allow us to rethink the rapport between human existence and animal life qua a relationship of mutual overlap and conglobation. In his most explicit, albeit fleeting, references to animal being, Patočka seems to establish a clear distinction between the ontological structure of the animal and the human. He marks such distance by denoting certain traits that he deems particular to human existence. Nevertheless, the present study aims to show that the Patočkian existence can affirm itself only by rescuing the biological roots of the possibilities within which it lives and the vital layer of the phenomenal field to which it opens. In doing so, human existence, as is argued in the last paragraph, brings to maturation an original ek-static tendency which already vibrates in the animal's relationship with its own environment.
\end{abstract}

In the development of his philosophical-phenomenological output, Jan Patočka never offered a systematic account of the relationship between human existence Creative Commons Attribution License (http://creativecommons.org/licenses/by/4.0). 
and animality. Rather, the Czech philosopher made fleeting, fragmentary, yet significant references to this relationship. Here, I will try to retrace the Patočkian phenomenology of the animal, of the living, by collecting and linking these fragments.

By focusing on the most pertinent of Patočka's considerations of animality, it will become clear that - seemingly moving away from the guidelines drawn by Heidegger's thought - he seems to engage himself in the identification of specific traits differentiating the human being from the animal.

In the 1974 text Problém počátku a mista dèjin (The Problem of the Beginning and the Place of History), a preparatory essay for the Heretical Essays on the Philosophy of History, the Czech philosopher posits historicity as the peculiar element distancing the animal from the human dimension: "Unlike man, the animal - like the rest of the litter - is not a historical being." ${ }^{\prime}$ Patočka establishes a coincidence between 'historicity' and 'responsibility' (zodpovědnost) that - as 'sacrifice' (obět') for an indefinite other that does not guarantee any reciprocal movement - it disables the circularity through which the natural-animal life flows.

One year later, in the Heretical Essays in the Philosophy of History, Patočka shows that the straightening and historicising movement of 'responsibility' is prepared and therefore sustained by 'work' (práce) which, as such, is not among the animal's capacities. ${ }^{2}$

Moving backwards along Patočka's works we find the famous 1967 text The Natural World and Phenomenology. Here, the animal is only referred to once, when Patočka distinguishes the essential core of the human being from that of a god, stone, or animal, all of which share in a common "being already made". 3

Continuing this reverse chronology, one can focus attention on the 1952 text Čas, mythus, vira (Time, Myth, Faith), where the author excludes the animal from temporality. Unlike the human, the animal does not live temporally, does not project. Rather, it is completely absorbed, gripped, by its own present. ${ }^{4}$

Many references to the animal occur in Hegelova Phenomenologie ducha (Hegel's Phenomenology of Spirit), a still-unpublished work resulting from a series of lectures on Hegel's Phenomenology that Patočka gave at Charles University during the academic year 1949-1950.

\footnotetext{
Patočka Jan, "Problém počátku a místa dějin”, in Patočka J., Péče o duši III, Praha, OIKOYMENH, Sebrané spisy Jana Patočky 3, 2002, p. 286. Translation by the author.

2 Cf., Patočka Jan, Heretical Essays in the Philosophy of History, Chicago and La Salle, Illinois, Open Court, 1996, p. 15.

3 Cf. Kohák Erazim, Jan Patočka. Philosophy and selected writings, Chicago and London, The University of Chicago Press, 1989, p. 250.

4 Cf. Patočka Jan, L'art et le temps, Paris, P.O.L, 1990, p. 31.
} 
By taking on the Hegelian point of view (filtered through Kojève and, therefore, Heidegger), Patočka performs the operation of removing from animality some of the features which are peculiar to what he describes as the essential structure of the human being: love, mortality, freedom, and perception.

In love, the human does not give himself on an animal level; love does not only affect the animal inclination of the human. (...) Love, for Hegel, does not mean a substantial mystical bond, but the dimension in which individuals are worthy of being different. This difference, as Kojève points out, is only possible because death exists - and this only for the lovers - not just objectively as for the plant and the animal. ${ }^{5}$

By engaging itself in the dedication to the other, the lover renounces the centrality of their self, running the risk of suffering the abandonment from the other, which it loves. Tackling the peril of losing the loved one, the human experiences the existence of death and opens to a possibility which cannot be lived by the animal.

By lacking the experience of death, the Patočkian animal described so far stays further on from time, absorbed in its own present. Unlike the human existence, it does not manage, in consequence, to go beyond the presence of the being standing before it and, thus, to relate to the totality, the appearance field, which any being comes from. To be more precise, the animal does not need "an explicit rapport to the totality - it is the totality itself, it is part of it". ${ }^{6}$ Because of the absorption in its environment, the animal belongs to the totality that brings to manifestation the entities by which the animal itself fulfills its necessities. Consequently, the absence of a relationship with totality impedes the animal's ability to work. Work, in fact, consists of transforming a being into another. Therefore, it can be carried out only by a being able to glimpse the horizon from which the new being, the product, appears.

It is undeniable that, in the references which have just been retraced, the Patočkian animal appears by virtue of its condition of lacking and as ontologically distant from the human being. ${ }^{7}$ Nevertheless, the development of the following sections

5 Patočka Jan, Hegelova fenomenologie ducha, unpublished manuscript (1949-50), The Jan Patočka Archive in Prague, p. 25. Translation by the author.

6 Patočka Jan, Le monde naturel et le mouvement de l'existence humaine, Dordrecht/Boston/London, Kluwer Academic Publishers, 1988, p. 175.

7 About the distinction between the animal life and the human life in Jan Patočka, see Frogneaux Nathalie, "Le mouvement de lêtre vers la vie: une lecture de Jan Patočka", in Ebisu, 40-41, 2008, pp. 127-140. See in particular the first, second and third paragraph (from p. 129 to p. 135): here the author distinguishes human life from that of the animal on the basis of movement. This is a faculty that human existence cannot share with the animal, which, in fact, is characterised by the "closeness, the absence of openness to itself" (ibid., p. 129). 
will show that, in some places of Patočka's phenomenological work, he implicitly calls into question the ontological difference between the human and the animal in order to recover a certain animal foundation of the human ontological structure. I am referring here to the openness to the phenomenal background, from which both being and human existence itself can achieve the light of manifestation.

By analysing texts from the late 60 s and early 70 s, and by reconstructing Patočka's review of some of the cornerstones of Heideggerean phenomenology, the following pages will attempt to demonstrate that the openness which characterises human existence rises from a primordial, latent, ek-static inclination which, paradoxically, is revealed by the animal precisely in its own closeness to and absorption in its own environment.

Now, in order to bring to the surface the ek-static character of the Patockkian animal, it is necessary to consider his rethinking of the Heideggerian notion of 'project'. Indeed, framing the Patočkian conception of project will allow us to understand existential possibilities as something stemming from a primary field of biological possibilities, capacities for bodily satisfaction.

This comprehending of the vital origin of possibility will permit us to posit that, with Patočka, existence inherits its peculiar openness from its own naked corporeality. In turn, the individuation of the naked origin of the existential disclosure will pave the way to recovering the animal origin of existential ek-staticity. In other words, by thinking, with Patočka, through Heidegger's categories, we will go beyond the Heideggerian conception of human existence and of its long ontological distance from animality.

\section{II}

In Patočkian phenomenology, we can see the "disclosure" (Erschlossenheit) of human existence emerging from an essentially involuntary corporeal motility, which always precedes subjective volition. In fact, such motility is in turn caused by the corporeal tension towards a fulfillment of the open nothingness of vital necessities.

In this context, the human openness to phenomenality establishes itself as an auto-overturning, a spontaneous suspension of a naked life that is inevitably marked by existential nullity because of its own nature. Effectively, it is as if the naked life elevates itself from the biological stage via a decisive boost prompted by its very nakedness. Patočka guides us to such a concept of existence with a radicalisation, and therefore a critique, of the Heideggerian notion of "projection" (Entwurf). 
Here I refer to a text entitled Tělo, možnosti, svět, pole zjevování (Body, Possibility, World, Field of Appearance). It is useful here to quote some lines concerning the notion of possibility.

The I as realizer in the body, the mediating body. A totality of possibilities, faculties, abilities, appetites, desires... My possibilities always question me as factual characters, which attract and repel. ${ }^{8}$

Some pages later we read:

The projection of possibilities is an entirely possible purpose, but a constructive purpose, not a phenomenon.

It is evident that it is only because I can that the things uncover to me in the context of this 'power' (...) Nevertheless, it is only because the things contain appeals to the realization that the I which can shows itself in its 'power' (...) I would not have any possibility if I had not means for possibilities, for my possibilities. ${ }^{9}$

In the light of the above quoted extract, one could affirm that, by radicalising the feature of passivity in the Heideggerian idea of the project as let-the-possibilities-be starting from a condition of thrownness (Geworfenheit), Patočka refuses the Heideggerian project's implementation of "understanding" (Verstehen), because he sees the expression of a consolidated residuum of "subjectivism" in it, an "undetermined idealism". ${ }^{10}$ For this reason, the philosopher denies the project a phenomenological status: "there is no phenomenological project of possibilities". ${ }^{11}$ Patočka reinterprets the project as the realisation - experienced from existence itself - of a "field of possibilities" that are open, freed from the world, from the things themselves. More specifically, things themselves release the feasible possibilities through their use, by asking existence to realise itself with the implementation of such usabilities. ${ }^{12}$

\footnotetext{
Patočka Jan, Papiers phénoménologiques, Grenoble, Jérôme Millon, 1995, p. 117.

Ibid., p. 120.

Ibid., p. 125.

Ibid., p. 125.

On Patočka’s critique of Heidegger's thought, see Barbaras Renaud, Loverture du monde: Lecture de Jan Patočka, Chatou, Editions de la Transparence, 2011, pp. 89-118. Moreover, on Patočka's critique of Heidegger's notion of Entwurf, see Jacquet Fredric, Patočka. Une phénoménologie de la naissance, Paris, CNRS Editions, 2016; see especially p. 71.
} 
Now, in a move that recalls Merleau-Ponty, the object-like background of the world feeds this releasing of possibilities by establishing a chiasmus-like relationship with the "living body" (Leib). In fact, because of this privileged relationship of implication with things, Patočka's body functions as a centre of mediation: it feels the call of object-like possibilities, spreading them alongside the existential structure to which it is connected and offers itself to responsible existence as an essential contribution to the realisation of the field of possibilities. Therefore, one can include Patockka in the circle of critics - led by Levinas - who identify the vulnus of Heideggerian existence in its lack of corporal consistency and thus see the constitutive 'openness' of its existence as a stream that is nourished and emerges from the flow of possibilities that immanently courses the mutual entwinement of things and the "living body". 13

As one can understand from the first lines of the previously reported quotation, the chiasmus-patterned connection between the "living body" and object mass established by Patočka is an elemental relationship: "a totality of possibilities, faculties, capabilities, talents, desires, needs... First and foremost, my possibilities consult me as factual entities that attract or reject". ${ }^{14}$

I am now going to quote another significant passage from Natural World and Phenomenology:

It is clear that the things that we handle and that we understand precisely through their manipulation are the things, which serve our needs, needs, which are implicated by our bodily functions and by our ability to provide. And such needs do not exist in isolation, as a single reality closed in and of themselves, but as concrete references: a key in the hands of a blacksmith refers to the lock, to the material used and to the lathe. Instead in the hand of the tenant it refers to the room with its separateness, its furniture, its contrast to the outside, to the workplace, and so on. ${ }^{15}$

13 On the centrality of the body for the existential projection of possibilities in Patočka's phenomenology, see Barbaras Renaud, Introduction à une phénoménologie de la vie, Paris, Vrin, 2008. Consult in particular the third chapter, second part, first paragraph, "La phénoménologie dynamique". At the beginning of the paragraph (p. 104), the French phenomenologist defines Patočka's conception of the body as the possibility of moving. In consequence, he comprehends it as a centre of spreading possibilities, which, by arising from the original corporeal possibility of motion, are irreducible to any existence's free decision. This, as such, is grounded upon a primal layer of passivity resembling the affectivity thematised by Michel Henri. See also Novotný Karel, "Corps, corps propre et affectivité de l'homme", in Les Études philosophiques, 98, 3, 2011, pp. 375-393.

14 Ibid., p. 117.

15 Patočka Jan, "Přirozený svět a fenomenologie", in Patočka J., Fenomenologické spisy II, Praha, OIKOYMENH, Sebrané spisy Jana Patočky 7, 2009, p. 221. Translation by the author. 
The idea expressed by Patočka in these lines is clarified and strengthened a year later in Natural World and Phenomenology, in Koncept přednášky o tělesnosti (Draft Lecture on Corporeality). Here, the author offers a further clarification on its idea of possibilities, explaining them as actions which as such process "as a modifications of the thing." 16 These modifications, in turn, are mostly "necessary to prolong and renovate life, so that life itself manages to stand in the exact place where it already is". ${ }^{17}$

Patočka recalls, radicalises and thus goes beyond Levinas' work on "enjoyment". He sees the thing as an element that fills the emptiness carried by the intention to fulfill the body, a body that, as Levinas would say in Totality and Infinity, is basically naked, destitute. Therefore, the possibility, the usability that originally asks existence to project, first and foremost comes from a movement of attraction or rejection - carried out by the elements - the elemental basis of the world - on the naked body. In other words, the possibility emerges from (and continuously returns to) the opportunity for biological satisfaction that is promised to the needy body by the element.

One could otherwise say that Patocka reinterprets that Heideggerian "world-environment" (Umwelt) as radicalised on a field belonging to the philosophy of life. To illustrate: the key in the hand of the blacksmith has its "for" (Wozu) in the lock and in the lathe, and its "in order to" (Um-zu) - which is to say, its usability - in the opening and closing of the door. However, the private, intimate handling that the blacksmith makes of the key reveals that the entire operation essentially recalls the naked body's need for protection from the outside, a need itself characterised by the naked body of the blacksmith. Hence, the usability of the equipment is outlined and configured from the possibility of biological fulfillment and ultimately reconnects to it. The "for" emerges from the cavity dug in the naked body by biological need; the "in order to" is developed starting from the ability to fill, belonging to the elemental essence of the equipment. Therefore, the "totality of involvements" (Betwandtnisganzheit) [celek toho, jak to s věci stoji],, ${ }^{18}$ the network of object-like entities in which every tool works "for" the other, is so to speak irradiated from a primary totality of biological fulfillments, of connections between the elements and the needs that can be satisfied.

The naked body moves around a totality of fulfilments; the connection between elements and needs becomes for the naked living body a background for its orientation. Naked life as such has always stretched beyond the instinctual circle

16 Patočka Jan, Papiers phénoménologiques, op. cit., p. 70.

17 Ibid., p. 70.

18 Cf. Patočka Jan, "Přirozený svět a fenomenologie", op. cit., p. 121. 
and shown, right in the creases of its closure, a break that anticipates and prepares for the existential life. ${ }^{19}$

\section{III}

The analysis developed in the previous paragraphs offers the opportunity to grasp the pre-original excess marking naked life as conceived by Patočka. To be more precise, the nakedness of human life has been acknowledged as the indispensable springboard for existential openness to those possibilities within which existence is and can be, as such.

In its nakedness, the human being lives and comprehends itself as an animal, as if it were an animal. Yet better, it centers its life on its animality. This is why the inquiry on the naked origin of the existential breach leads toward a reconsideration of the Patočkian reflection on the relationship between human existence and that of the animal.

Actually, as the dig into Patočka's corporeality has brought us to recognise a primal disclosure in the naked layer of the human life, the analysis which follows will, in parallel, help to retrace a pre-original glare of ecstatic-ness in the animal relating to its surroundings.

Here we must focus again on Patočka's thoughts on "projection". Indeed, it is via the rethinking of "projection" that Patočka reaches the idea of a relationship of mutual implication in the difference between the animal dimension and the human, existential dimension. In the final part of Draft Lecture on Corporeality, Patočka

19 In the spectrum of works devoted to the problem of life in the context of Patočka's phenomenology, the most substantial and significant contribution is undoubtedly that offered by Renaud Barbaras in the third chapter of the aforementioned Introduction à une phénoménologie de la vie: Le partage du mouvement.

The present essay opens up a perspective that, at first glance, coincides with that of Barbaras, but in a second moment distances itself from it. In fact, I hold that the French philosopher accomplishes an ambivalent movement toward the Patočkian conception of life. On the one hand, he recognises in Patočka's phenomenology the centrality of corporeality, which is precisely defined as "possibilité première qui possibilize toutes les autres possibilités" (ibid., p. 101). In this way, Barbaras emphasises the distance that Patočka takes from Heidegger, who "n'intègre pas la corporéité aux existentiaux du Dasein" (ibid., p. 102). On the other hand, however, Barbaras seems to recover, in my opinion, a Heideggerian standpoint by devaluing the biological trait of Patočkian life. Actually, the French phenomenologist defines life as a "fundamental tendency of existence". As if life was lived only on the basis of the existential structure. Therefore, the biological-instinctive feature is unable to play a relevant role within the movement of existence. In fact, as he clearly states, "vivre, c'est ne pas se maintenir en vie, satisfaire ses besoins ou répondre aux sollicitations du milieu: c'est exister d’une certaine façon" (ibid., p. 123). 
analyses Heidegger's meditation on human affectivity, on feeling, starting from that fundamental existential determination called "emotional situation" (Befindlichkeit). As Patočka argues, affectivity can be understood, from a Heideggerian standpoint, as a crucial step of finding oneself and, in consequence, as a mere springboard for projecting. ${ }^{20}$ However, with Patočka himself, we might ask whether Heidegger's reasoning does not presume and conceal that "elementary protofact of harmony with the world", ${ }^{21}$ where there is an absolute absence of distance from things.

This question prompts us, following Patočka, to examine the ways of being of the animal and of the child. ${ }^{22}$

The animal and childhood pre-linguistic relation to the world is a relationship of pure feeling. (...) The animal and the child are immersed in a sympathetic relationship, a relationship of compassion (soucit) with the world. ${ }^{23}$

Patočka sees in the passivity and opacity of the "emotional situation" the way of being of the child, who is considered to be in a relationship of contiguity with the animal. Therefore, if existence originally projects thanks to the resources provided by emotionality, it designs and realises possibilities that emerge from the dimension of childhood - and animal - passivity. In other words, human and animal existence meet and mutually converge where a shared element with the child makes them similar: a condition of constitutive, spontaneous harmony with the world. ${ }^{24}$

(...) The animal and the child are entirely caught in the present as such [italics R. P.]. They are not interested in their own being, they do not relate to it, but they only tend to the exterior, to an outer being that shows itself in the connection of their actions, not as being, but only as present.

However, in this present not only what we call presence of the thing is present in the context of its understanding; here, the whole situation is penetrated by an implicative, atmospheric, total stream, which the sentient creature belongs to. This means that such a global perspective has its global corresponding: this look is traversed by a tension that

20 Cf., Patočka Jan, Papiers phénoménologiques, op. cit., p. 101.

21 Patočka Jan, Body, Community, Language, World, Chicago and La Salle (Illinois), Open Court, 1998, p. 133.

22 Cf., Patočka Jan, Papiers phénoménologiques, op. cit., p. 101.

23 Ibid., p. 101.

24 On this issue, see p. 390 of Karel Novotnýs article mentioned above: "Corps, corps propre et affectivité de l'homme". Here the author, quoting Patočka's Draft Lectures on Corporeality, stresses the fact that in the animal and childhood dimensions, existence is already moved before becoming able to freely move itself. 
pushes it out of itself and always moves the creature in a way that keeps it in a certain being moved. ${ }^{25}$

In the quoted text, we notice that Patočka presents again - more or less - the scheme used by Heidegger in The Fundamental Concepts of Metaphysics to define the peculiar ontological characteristics of the animal environment.

The first part of the quote, in fact, seems to recall that passage in The Fundamental Concepts of Metaphysics. World, Finitude, Solitude, ${ }^{26}$ where Heidegger refers to animal "behaviour" (Benehmen) and specifies that the entity, the disinhibiting of the animal spirit can never be comprehended as entity by the animal itself, which as such stays "poor of world". The disinhibiting is opened - offered - to the animal, but the manifestative background is unrevealed. Starting from this background, it would be possible to understand the sense of what disinhibits, the horizon that would make possible the understanding of the disinhibiting ring as being. ${ }^{27}$

However, from a Heideggerian point of view, something does not make perfect sense in Patočka's words. In the following sections of the passage, the Heideggerian structure, already threatened by the importance given by Patocka to the concept of consonance, ${ }^{28}$ collapses. For the Czech philosopher, the "present-at-hand" (Vorhandenheit) of the "disinhibiting ring", that is in harmony with the animal, has a global, atmospheric nature, and goes beyond every single disinhibiting that is simply present. Thus, the animal anticipates by looking at this presence, the living being, as if it were stretching ahead.

In this respect, four years later, Patočka briefly writes in the already mentioned notes entitled Body, Possibility, World, Field of Appearance: "The animal, the animal unit... = possible-being"29. Going back to Draft Lecture on Corporeality, Patočka makes himself even clearer a few pages later:

The role of motility, of the emotional sphere, of the imagination in feeling, of the sensual harmony with the world shows that this cohesion has a cosmic nature even though

25 Ibid., p. 101.

26 Heidegger Martin, Die Grundbegriffe der Metaphysik. Welt - Endlichkeit - Einsamkeit, Frankfurt am Main, V. Klostermann, 1983, Heidegger Gesamtausgabe 29/30; English translation: Heidegger Martin, The Fundamental Concepts of Metaphysics. World, Finitude, Solitude, Indiana University Press, Bloomington, 2008.

27 "There is no apprehending [Vernehmen], but only a behaving [Benehmen] here, a driven activity which we must grasp in this way because the possibility of apprehending something as something is withheld [genommen] from the animal. And it is withheld from it not merely here and now, but withheld in the sense that such a possibility is 'not given at all”' (ibid., p. 247).

29 Ibid., p. 121. 
it is not real knowledge or understanding. With this harmony, the animal stands beyond the border of organism, beyond its private being, because the cosmos itself is something more than mere res extensa. ${ }^{30}$

Therefore - working on the Heideggerien concepts starting from the quoted passage - the action of "absorption" (Eingenommenheit) in the "environmental circle" (Umgebung) keeps the animal on the other side of an understanding of the disinhibiting as entity. However, the practice of this attractive force as such causes in the animal a movement of outflow, a movement of projection that spontaneously seems to outline ecstatic existence.

Simultaneously, the absorbing circle, by absorbing and sinking the living in itself, expands - beyond mere elemental spatiality - into a global background of orientation, in atmospheric, cosmic presence, which is, we could say, the basis for the simple presence of every disinhibiting. To Patočka, such a background originally outlines the manifestative openness, the appearance field which the animal does not question, but experiences.

With this regard, in Body, Possibility, Word, Field of Appearance Patočka writes: "The original possibilities, the world, are nothing but a field in which the living exists and that is co-original with the living". ${ }^{31}$ As if, in the vitalistic perspective here adopted by Patočka, the original source of appearance basically coincides with the harmonious relationship between the animal and its environment. ${ }^{32}$

More precisely: through the analysis of the above quoted extract from Natural World and Phenomenology the 'totality of fulfillments' rediscovers itself - in Patočkian thought - as a "field of possibilities", irradiated from a primary structure

30 Ibid., p. 104.

31 Ibid., p. 124.

32 It could be useful to compare this article with the one written by Duicu Dragoş, "La 'tendance' de la vie animale chez Patočka et le problème de la différence anthropologique", in Burgat Florence, Ciocan Cristian Phénoménologie de la vie animale, Bucarest, Zeta Books, 2015. Here the author, by working with Patočka on Aristotelian and Husserlian categories, individuates the anthropological difference in a perceptual dynamic. As Duicu efficaciously explains, the animal can perceive the identical in the variety of manifestations. However, it lacks, unlike the human, the possibility to "totalize the totality", namely to recognise the "unity of the movement" which the different manifestations come from. This is why, as Duicu affirms at page 167, Patočka adheres to Heidegger's definition of animal as "poor of world".

In contrast, the present article, by critically working on Heideggerian categories, considers animal life from a different perspective: though the Patočkian animal does not properly experience the phenomenality, it accomplishes an original movement of excess, which anticipates and makes possible the human's "formation of world". 
interweaved from biological needs. ${ }^{33}$ Now, in the light of the quoted sentence, the "worldhood" (Weltlichkeit), the horizon of original possibilities, seems to open up from the harmony between the living and its world, from the "stunned condition" of the animal in its disinhibiting.

\section{Conclusion}

By making a comparison with Heidegger's notion of the "totality of involvements", it is possible to understand that Patočka's field of possibilities emerges from a pre-original field of biological possibilities which, in turn, stem from the human's primary condition of nakedness and animality.

Furthermore, as we can read in the last paragraph, the animal's "absorbing circle", as thematised by the Czech thinker, reverses itself into an atmospheric, cosmic dimension that works as the horizon from which the disinhibiting entity presents itself. Therefore, the Patočkian animal reveals a certain tension toward openness, which resembles that which characterizes human existence. Furthermore, it anticipates and prepares the excess and ek-static character of human existence. Consequently, it can be inferred that Patočkian existence cannot open to phenomenality without a prior heritage of animal ek-staticity, thereby reducing its ontological distance from the animal itself and recovering a relationship of mutual consonance with it.

Riccardo Paparusso is a professor (professore incaricato) at the Philosophy Faculty of the Pontifical University of Saint Thomas Aquinas in Rome. He also teaches philosophy at Rome International School. He is an expert on Patočka's thought. His most recent articles include: The End of History and After: Rethinking Kojève and Patočka on the idea of Post-History (2016); La hyle nullifiée. Réflexions autour de l'interprétation patočkienne du concept aristotélicien de phyisis (2015).

E-mail: paparussoriccardo@yahoo.it

33 In this vitalistic perspective, see also: Hagedorn Ludger, “Quicquid Cogitat': On the Uses and Disadvantages of Subjectivity”, in Učník Lubica, Chvatík Ivan, Williams Anita (eds.), The Phenomenological Critique of Mathematisation and the Question of Responsibility: Formalisation and the LifeWorld, Dordrecht/ Heidelberg/London/New York, Springer, 2014, pp. 89-102. It could be helpful to consult, above all, the fifth paragraph, entitled The Magic Concept of Life, where the author explains that, in Patockka's thought, the Nietzschean theme of life impacts firstly the phenomenological concept of the "natural world" (prirozený svět). 